„Kwartalnik Filmowy” no. 116 (2021)

ISSN: 0452-9502 (Print) ISSN: 2719-2725 (Online)

https://doi.org/10.36744/kf.946

(c) Creative Commons BY-NC-ND 4.0

Fatma Edemen

Jagiellonian University

https://orcid.org/oooo-0003-4432-8991

\title{
Independent Film for Solidarity of Traumas in the Cinema of Turkey
}

\begin{abstract}
Keywords:
independent film; memory studies; multidirectional memory; travelling memory; postmemory

Abstract

Michael Rothberg introduced the concept of multidirectional memory in Multidirectional Memory: Remembering the Holocaust in the Age of Decolonization (2009). Later, many other scholars used his idea to analyze works of art, including films. Although multidirectional memory generally focuses on the possibility of establishing solidarity between memories/traumas that are geographically or culturally distant from each other, in this article it will be argued that this concept is also crucial within coexisting multicultural and multitraumatic societies. The concept of multidirectional memory, and subsequently concepts such as travelling memory and postmemory, will be examined through the analysis of an independent production from Turkey, Özcan Alper's film Future Lasts Forever (Gelecek Uzun Sürer, 2011). With the help of critical film analysis, the multidirectional memory of Turkey's traumatic past will be discussed as an opportunity to practice solidarity.
\end{abstract}




\section{Introduction}

Films are frequently used to construct narratives on traumatic memories. Notably, films focusing on traumatic memories cannot go beyond independent cinema in countries that refuse to confront their traumatic past. Independent filmmaking in these regions has also come to the fore with the strength of its connection with the re-imagination of past events and willingness to confront them, perhaps from its earliest days.

This article's primary purpose is to reveal the traumatic encounters in the independent cinema of Turkey ${ }^{1}$ and examine the use of multidirectional memory ${ }^{2}$ as an analytical tool. Future Lasts Forever (Gelecek Uzun Sürer, dir. Özcan Alper, 2011) is a prominent example of the independent cinema of Turkey, and it is essential to this discussion due to its focus on memory and traumas in the region. A close reading of the film, from the conceptual perspective of multidirectional memory, travelling memory ${ }^{3}$, and postmemory, ${ }^{4}$ will help understand how cinematic narratives can represent the solidarity of different traumas in Turkey.

Representation of traumatic memory of the people of Turkey was taken over by the independent cinema from the very beginning. After the first military coup, held on May 27, 1960, the new constitution formed in 1961 gave some progressive rights to the people of Turkey, the right to strike in particular. This period of political freedoms being recognized lasted, with some ups and downs, until the second military coup on September 12, 1980. The libertarian nature of this period also deeply influenced filmmaking practices. Soon after these new regulations, Turkey's new way of filmmaking emerged, oriented particularly against the mainstream Hollywood-like aesthetic of "Yeşilçam ${ }^{5}$ cinema". New independent filmmakers preferred European arthouse aesthetics. ${ }^{6}$

\section{The journey of independent filmmaking in Turkey}

While the independent filmmaking style that came to the fore in the early 1960s emerged within the framework of social realism and national cinema, it took a more radical turn in 1968. Murat Akser summarizes the independent cinema in Turkey in a few aspects. Independent cinema in Turkey, according to Akser, may be defined and classified based on the following characteristics: Independent film producers, social concern about modern-day alienation, urban and western-trained filmmakers, non-profit, non-commercial restricted audience, state and/or international finance, an artistic festival cinema that opposes censorship and has a political expression. ${ }^{7}$

From the early 1960s, filmmakers followed an aesthetic that can be traced to the Italian Neorealism. Like the Italian Neorealists, independent filmmakers of Turkey focused on narrating real people's daily lives, portraying particularly workers, peasants, and underrepresented "others" of the time. They often narrated civil disobedience, rural migration, urban sprawl, and strikes. Prominent directors of the 1960s were Halit Refiğ, Metin Erksan, Memduh Ün, Lütfü Ömer Akad, Duygu Sağıroğlu, and Ertem Göreç, and generally they followed the leftist writer Kemal Tahir. Metin Erksan's receiving the Golden Bear Award from the Berlin Film 
Festival for Dry Summer (Susuz Yaz, 1963) was a transformative moment for the film industry of this period. Banned in Turkey, the film was secretly smuggled to Germany for the festival. After the film won the award, not only Erksan but also the cinema of Turkey gained international recognition. ${ }^{8}$

Radical filmmaking started in Turkey in 1968 with the establishment of the Young Cinema Group (Genç Sinema Topluluğu), which brought together filmmakers with different ethnic and religious backgrounds, including Greek, Jewish, Turkish, Kurdish, and Armenian. Between 1968 and 1971, they also published the journal Genç Sinema (Young Cinema) to promote their ideas. They were protesting the presence of the United States in Turkey and following the left-wing politics of the time. Their prominent documentary film, Bloody Sunday (Kanlı Pazar, 1969), presents student protests in Istanbul against the US Sixth Fleet, which was based in Turkey. During the main rally on February 16, 1969, right-wing groups brutally attacked the protest; as a result, two left-wing protesters were murdered and many injured. In Bloody Sunday, the group of filmmakers not only recorded the event that happened that day, but also made a statement about these traumatic experiences. They used Mikis Theodorakis's music composed for Costa Gavras's feature film $Z$ (1969) in the time of the Greek military junta. ${ }^{9}$ With this choice, the group also indicated the traumatic events and political struggles that made these neighbouring countries closer.

Kurdish actor and director Yılmaz Güney became a prominent figure in the 1970s independent filmmaking scene. Güney was influenced by Italian Neorealism and the Latin American Third Cinema. He was open about his leftist and pro-Kurdish views, and it is possible to connect his films with his political activism. In 1982, he received the Palme d'Or at the Cannes Film Festival for his film The Road (Yol, dir. Şerif Gören, 1982) while exiled to France (due to the fact that Güney was imprisoned at the time, his assistant Şerif Gören had directed the film under Güney's guidelines, communicated from the prison). ${ }^{10}$ The Road is also important for Kurdish identity and filmmaking by recognizing the land of Kurdistan and using the Kurdish language. Güney is considered a significant filmmaker for Turkey's independent cinema, but he is also prominent as a Kurdish director.

Dividing independent filmmaking in Turkey into two broad periods, the military coup of September 12, 1980, should be considered a turning point. The rapid and complex political changes of the 1980s profoundly affected film production. When the Turkish Army gained control of the government, thousands of people were slaughtered, tortured, and arrested in the following years, and the military administration executed 50 people on a court order. In 1983, the right-wing Motherland Party (Anavatan Partisi, AP) won the elections. With the 1980s, neoliberal policies came to the fore in the country. Until the new AP government's first legal regulation on privatization in 1984, the economy was dominated by the state. ${ }^{11}$ Film production in Turkey declined more than ever during this time. Most films made during this period are about the grim reality in the aftermath of the coup. Many independent filmmakers were detained after the coup or faced lawsuits.

Surprisingly, during this dismal period for social movements in the 1980s, a women's movement emerged and rose to prominence. Women involved in leftist politics before the coup tended to gravitate toward feminism. Women in Istanbul, Ankara, and Izmir, in particular, created reading groups and house meetings. The 
first legal demonstration since the coup was organized on May 17, 1987, under the banner Women's Solidarity March Against Beating (Dayağa Karşı Yürüyüş). ${ }^{12}$ Not only were women becoming more active in politics during this time, but they were also becoming more visible in the arts. Women's stories became more important, and several women-centred films were made.

Neoliberal policies that were introduced in the 1980s continued in the 1990s. Radio and television broadcasting, previously monopolized by the government, were now privatized. Between 1990 and 1996, Turkey's film production once again fell dramatically. Yavuz Turgul's The Bandit (Eşkiya, 1996), seen by almost two million people, was the picture that reversed this unfortunate trend. ${ }^{13}$ This period was considered the beginning of the New Turkish Cinema (Yeni Türk Sinemas1). According to Asuman Suner, Turkish cinema experienced a crisis of identity in the 1990s. This identity crisis resulted from the accumulation of problems that were not discussed in the public sphere. The adjective "new" emphasizes a break from the previous period. ${ }^{14}$ In the 1990s, co-productions began to be made. In particular, the establishment of Eurimages European Cinema Support Fund in 1989 opened a new path for producers and directors who wanted to make films outside the mainstream in Turkey. Turkey became a member of the Eurimages on February 28, 1990. ${ }^{15}$ External funding supported the independence of filmmakers. Prominent figures of the New Turkish Cinema include Nuri Bilge Ceylan, Zeki Demirkubuz, Semih Kaplanoğlu, Derviş Zaim, Reha Erdem, and Yeşim Ustaoğlu. They were also dubbed the festival auteurs of the 2000s by Murat Akser. ${ }^{16}$

Even though scholars and film critics coined the name New Turkish Cine$\mathrm{ma}$, it has never been a movement or an organized group. Several small collective efforts can be seen in the 1990s and 2000s. The New Filmmakers Movement (Yeni Sinemacilar) was another influential group that included such filmmakers as Serdar Akar, Önder Çakar, and Kudret Sabancı. On Board (Gemide, dir. Serdar Akar, 1998) was their first film. Their work is also known as "men's films" due to the male-dominated narratives.

Contemporary independent filmmaking in Turkey, which is the focus of this article, began in the mid-2000s. The establishment of the General Directorate of Cinema under the Ministry of Culture and Tourism of the Republic of Turkey in 2003 is another important milestone, as the institution started to offer financial support to directors in 2005. An essential organization of this period was the New Cinema Movement (Yeni Sinema Hareketi), which was founded in 2007. In 2010, its members created a union to help first-time filmmakers. At that time, the filmmakers' focus was the narratives of the underrepresented, the recollection of traumatic experiences, and the portrayal of topics not addressed in mainstream cinema. Özcan Alper, the director of Future Lasts Forever, which will be examined in this article, is also one of the active participants of the New Cinema Movement. As mentioned earlier, the distinctive feature of this group of filmmakers is that they conveyed a political message. It should also be noted that they came together in the period of the first peace process discussions between the Turkish government led by the Justice and Development Party (Adalet ve Kalkınma Partisi, AKP) and the Kurdistan Workers Party (PKK) to end the armed conflict. The filmmakers' effort to confront the past was directly connected with the country's current political situation. The peace process debates continued with varying success from 2009 
until a complete failure in $2015 .{ }^{17}$ This was also reflected in the films of the period. It can also be said that the period of the peace process was easier for directors to raise funds and enjoy artistic freedom.

Academics who demanded that the government lay down the guns in the Kurdish provinces released a declaration titled We will not be a party to this crime ${ }^{18}$ in 2015 and were targeted by the authorities, who accused them of "terrorist propaganda". The filmmakers, coordinated by the New Cinema Movement, issued a statement supporting the academics: Film Workers for Peace. ${ }^{19}$ The government threatened the 433 filmmakers who signed the declaration with a legal investigation and announced that their films would not get government funding. ${ }^{20}$ These conditions persist to this day; as a result, collaborative productions and foreign funds are now the primary funding sources for independent filmmakers.

\section{Özcan Alper as a filmmaker}

Özcan Alper, one of the founders of the New Cinema Movement, directed three feature films. It is possible to see them as analyses of the collective memory of the people of Turkey and of the country's history. Autumn (Sonbahar, 2008) follows the story of Yusuf, who was arrested as a young university student and after ten years of imprisonment regains his freedom. He returns to his hometown to trace his childhood and early youth memories. Yusuf meets a young sex worker from Georgia, Eka. While the film narrates the story of Yusuf and the collective memory of Turkey, it also follows the story of Eka and the post-USSR migration as a side story. Alper's last feature film, Memories of the Wind (Rüzgarm Hatıraları, 2015), narrates the story of Armenian artist Aram, who during the 1940s was forced to run away from Turkey to Soviet Georgia because of his political writings and anti-communist activity. Waiting to be smuggled to Georgia in the Black Sea region of Turkey, Aram also recalls traumatic experiences from his childhood, related to the relocation of Armenians that led to the 1915 genocide.

Alper did not receive funding from the Ministry of Culture and Tourism for his latest production. It was unusual for a director who had already made two successful films that travelled to several festivals to be refused governmental support. Alper mentioned in an interview that he believed he would have received funds if his protagonist was not Armenian. ${ }^{21}$ Alper did not study at a film school but trained at the Mesopotamia Cultural Center (Mezopotamya Kültür Merkezi, MKM). Even though MKM was a Kurdish initiative, Alper found himself there with his Hemshin ${ }^{22}$ national background. Later he wrote: MKM is the will to sing in their own language, write in their own language, and make movies in their own language, not only for the Kurds but also for all the peoples whose voices are not heard and are meant to be destroyed. ${ }^{23}$

Future Lasts Forever is not only Alper's own second production, but also the second feature film of his company Nar Film. Alper established it in 2009 to produce his own films, and later the company started to produce films by other directors as well. ${ }^{24}$ Nar Film collaborates with international production companies and finances its films through national and international funding, as is common in independent filmmaking. Future Lasts Forever was co-produced by Nar Film (Turkey), Arizona Films (France) and Unafilm (Germany). As stated in the credits, 
it was presented to the co-production markets of Paris Project (Paris Cinema Film Festival) and Crossroads (Thessaloniki Film Festival). It was financed by Eurimages, Turkish Ministry of Culture, Centre national du cinéma et de l'image animée (CNC) and Filmstiftung Nordrhein-Westfalen (NRW). As a result, the film is an example of independent filmmaking practice, which started in the 1990s and continues today, not only in terms of its subject and style but also in the way it was financed.

\section{Future Lasts Forever: Plot Summary}

Future Lasts Forever is Alper's only film in which he went beyond the borders of his home region, the Black Sea: he takes Sumru, a Hemshin like himself, on a journey to the historical Kurdish capital Diyarbakır. Sumru (played by Gaye Gürsel), a young ethnomusicologist, travels to Diyarbakir to work on her dissertation, in which she investigates elegies as testimonies of state brutality. Sumru interviews and documents the tales of family members whose relatives were forcefully disappeared by the authorities in the 1990s during the intense clashes between the Turkish Army and the PKK. Harun (Osman Karakoç), Sumru's boyfriend, joins the Kurdish rebels and leaves her a note, which is seen at the film's opening. Sumru's trip to Diyarbakır and the story-gathering procedure are connected to her search for Harun. Sumru encounters Ahmet (Durukan Ordu), a cinephile peddling pirate DVDs, on the streets of Diyarbakır. Sumru learns that her research can benefit from Ahmet's audio and video recordings from the conflicted period. Sumru and Ahmet begin their work at the city's Memory Centre, which houses the recordings and other archived artefacts. Through the recordings, Ahmet and Sumru witness the traumas and brutality endured by the Kurds in the region. Sumru discovers an old Armenian church while walking through the city's historic streets and meets Antranik (Sarkis Seropyan), an old Armenian man who lives in the church. When Antranik notices Sumru's resemblance to an Armenian girl, he asks if she speaks Armenian. Sumru responds that she can speak a little Armenian but mostly Hamshin language, a dialect of Armenian. Sumru and Antranik begin to form a friendship. She listens to Antranik's stories and tries to hear the voices of the Armenians who have vanished from Diyarbakır.

While listening to the recordings at the Memory Centre, Sumru hears a mention of her boyfriend Harun's village in Hakkari, east of Diyarbakir, in a territory considered dangerous. She sets out to travel there and invites Ahmet, who does not want to go at first, but later agrees. Through the camera shot of an old newspaper clipping that Ahmet was reading at the Memory Centre, the viewer learns that unknown perpetrators also murdered Ahmet's father in the 1990s. During their travel to Hakkari, Ahmet tells Sumru how he was traumatized by this murder as a young boy. They ask about the voice recording when they get to Harun's village at the end of the journey, and Sumru finds Harun's grave in the village. The film ends on the shore of the Siyasümbül lake, which Harun used to love very much. 

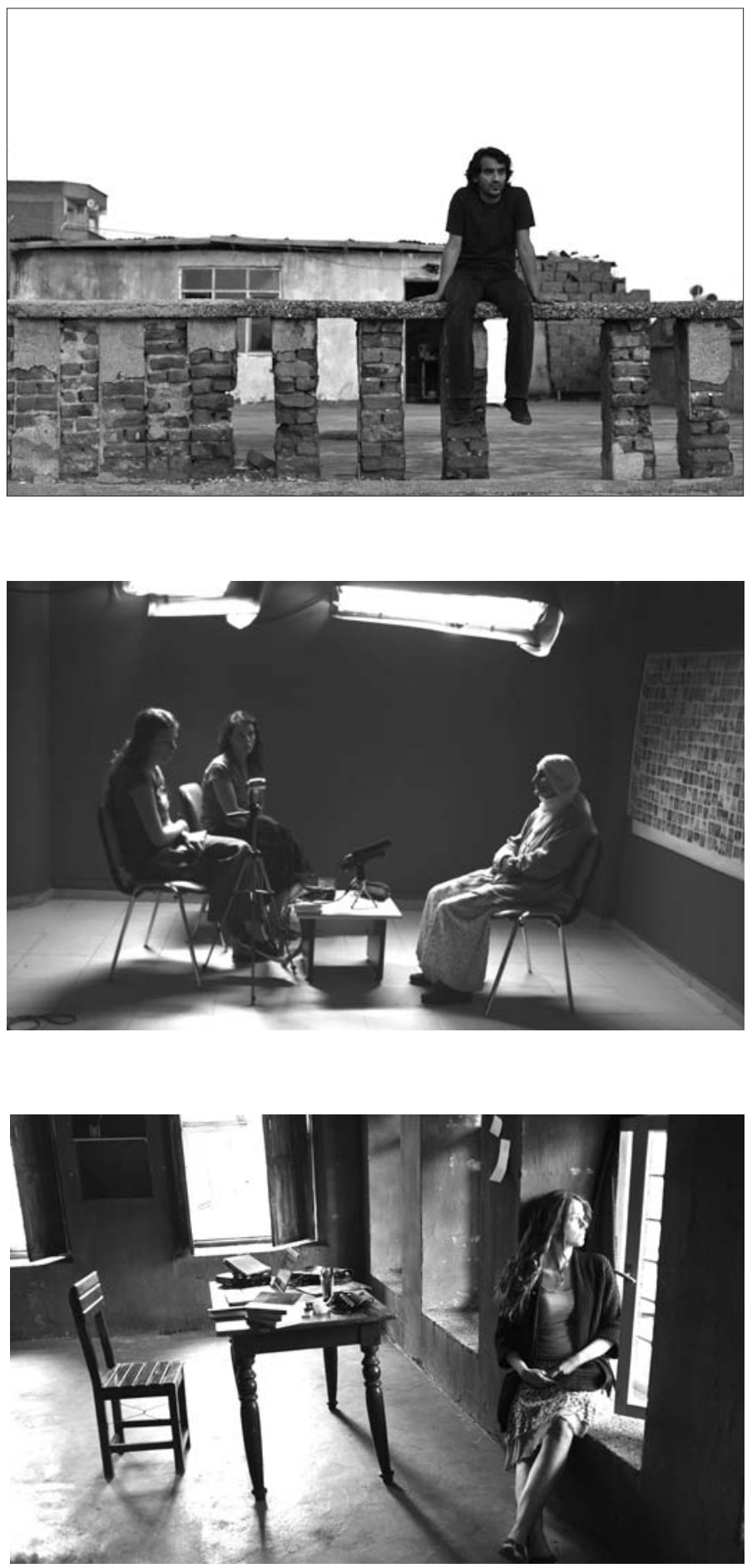

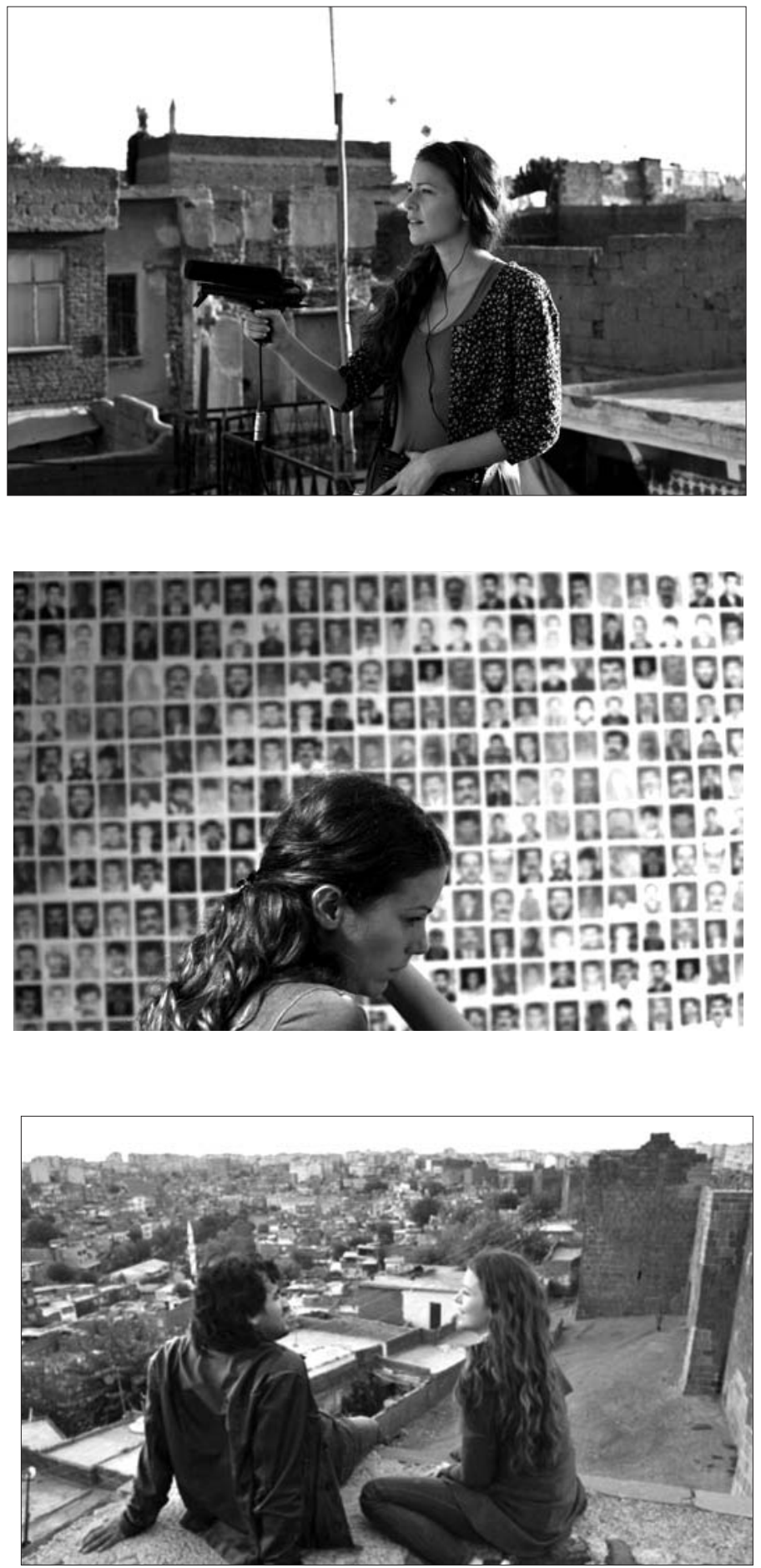


\section{Multidirectional memory, travelling memory-films, and postmemory}

In his seminal monograph Multidirectional Memory: Remembering the Holocaust in the Age of Decolonization (2009), American Holocaust and memory studies scholar Michael Rothberg opened up the discussion around the memory of the Holocaust and other traumatic experiences that are confronted in the public sphere. In his view, different collective memories face each other competitively, and this process can be regarded as a zero-sum struggle. ${ }^{25}$ He asks: When memories of slavery and colonialism bump up against memories of the Holocaust in contemporary multicultural societies, must a competition of victims ensue? ${ }^{26}$ According to Rothberg, another concept could potentially lead to solidarity in place of competitive memory practices: multidirectional memory. The scholar prefers to avoid binary, competitive positions, searching instead for the possibility of solidarity between different groups and regions. He also points out that the idea of uniqueness can create a dangerous hierarchy of suffering. ${ }^{27}$ He claims that when the productive, intercultural dynamic of multidirectional memory is explicitly claimed ..., it has the potential to create new forms of solidarity and new visions of justice. ${ }^{28}$ Rothberg also states that multidirectional memory is subject to ongoing negotiations, cross-referencing, and borrowing; as productive and not private. ${ }^{29}$

According to Rothberg, Holocaust remembrance influenced the creation of memory for other histories of violence around the world. He refers to slavery, the Algerian War of Independence, and the Bosnian genocide, among other events. The process of decolonization is still ongoing; however, for Rothberg, the period between 1945 and 1962 is critical for both Holocaust memory and the creation of European colonial memory, because the awareness of and knowledge about both events increased at that time. As a result, he discerns and acknowledges the connections and potential for solidarity between these two areas of memory. ${ }^{30}$

Although Rothberg searches for multidirectionality and the borrowing and adapting processes between memories on a global scale, I believe that multidirectional memory may also offer a way to connect memories that are considered isolated even when they concern the same country or region. Multidirectional memory has been hardly used regarding the discussions of historical events in Turkey. However, Kurdish researcher Adnan Çelik, discussed the multidirectional memory regarding the Kurdish conflict and the Armenian Genocide both in an article published in the pro-Kurdish daily Yeni Yaşam in Turkish language and in an article for Middle East Research and Information Project in English. Çelik briefly discusses multidirectional memory as a new mode of remembering that emerged in Turkey around 2000, leading to the solidarity of Kurdish and Armenian collective memories $^{31}$ : In Turkey, Armenian suffering has been included in the Kurdish victim-memorial regime, demonstrating the multi-directionality of memory formulated by Michael Rothberg. The public articulation of collective memory by distinct marginalized social groups can productively enable other groups to articulate demands for recognition and justice. In Turkey, 1915 becomes a prism for understanding the state violence that unites the different memories of marginalized groups: the Dersim massacres against the Kurdish Alevi community in 1938 , torture in the Diyarbakır prison in the 1980s and the atrocities committed against the Kurds during the 1990s. ${ }^{32}$ Çelik's point of view and the narrative of Future Lasts For- 
ever can be discussed together to think about memories and traumas that create a potential solidarity of Armenian and Kurdish collective memories.

Another concept useful in analysing the solidarity and multidirectionality of independent filmmaking in Turkey is travelling memory. German memory studies scholar Astrid Erll describes travelling memory-films as road movies and travel films, quest documentaries, anthology films, episodic films, or essay films - all of which address Europe and its transcultural memories through the depiction of performance of movement, through 'travel' on various levels. ${ }^{33}$ Memory can move through different levels, and travelling memory-films can include both actual and symbolic journeys. The film, according to Erll, is a transcultural memory practice, and all memories created in culture are transcultural, because borrowing and adapting processes are significant in the context of multidirectional memory. ${ }^{34}$ According to Erll, the portrayals of actual travel as in road movies and border crossing narratives, 'travel' in the film's structure as in films on migration and most documentaries, and travel as social circulation are three primary expressions of the travelling memory-film. ${ }^{35}$

Introducing the concept of postmemory, Marianne Hirsch started on an autobiographical ground. Recalling memories from her childhood in Bucharest, she states that they were linked with her family's past even from before she was born. She named people who experienced family memories from before their life as postgeneration. The postgeneration carries their families' Holocaust survivor memories. 'Postmemory' describes the relationship that the 'generation after' bears to the personal, collective, and cultural trauma of those who came before - to experiences they 'remember' only by means of the stories, images, and behaviors among which they grew up. But these experiences were transmitted to them so deeply and affectively as to seem to constitute memories in their own right. ${ }^{36}$

When one considers postmemory through the perspective of the film and memory interaction, many fictional features might be regarded as postmemory productions in and of themselves. Numerous films, particularly those that focus on social events, memories, and traumas, perform the role of storytellers for earlier generations. Such films preserve the memories of previous generations, but they often influence how subsequent generations recall events of the past.

\section{The notion of memory in Future Lasts Forever}

Future Lasts Forever takes place in the Kurdish region of Southeastern Turkey, between the cities Diyarbakır and Hakkari. Although Rothberg's work focuses on multidirectional memory dynamics and solidarity possibilities between the Holocaust and decolonization and between groups from different parts of the world, the narrative of this film shows that distinct traumas and memories can exist in the same region on a regional scale. The film attempts to depict the collective nature of traumas. Even Sumru's and Ahmet's personal traumas and memories arise due to the current Kurdish struggle and war. Throughout the film, Sumru understands that her boyfriend's leaving is not an individual matter, which is why she interacts with other inhabitants of the region later in the film.

Sumru meets with families of the people who were forcibly disappeared in the 1990s, in the time of armed clashes between the Kurdish national movement 
PKK and the Turkish Army. As a result of violent conflict that lasted for more than thirty years, many people lost their lives. At this very moment, the film focuses on the civilian Kurdish lives that were taken away due to the state's regional policies. People who speak as families of the victims in the film are actual real-life families of the murdered people. In these sequences, the film employs documentary practice and shows real traumatic experiences and memories. These scenes were shot in the Mesopotamia Association of Assistance and Solidarity for Families with Lost Relatives (Mezopotamya Yakınlarını Kaybedenlerle Yardımlaşma ve Dayanışma Derneği, MEYA-DER). The families are seated in front of a wall with photos of the missing persons in the backdrop, and they talk about the vanishing of their relatives. Some speak Kurdish; there is an interpreter next to Sumru. Interviewees were residing in villages closer to conflict zones. Since they refused to cooperate with the Turkish army against the rebels, their villages were burned down, and adult males in the community were executed. Through these experiences, the film says that virtually all relatives of the missing want to know where their family members' bodies are. They want a proper burial and accountability. One may argue that the film embraces and transmits this demand to the viewer.

Even though the story primarily depicts the trauma and sense of despair caused by the Kurdish conflict, it also includes a secondary narrative regarding Antranik, who lives in the city's historic Armenian church. Sumru and Antranik are connected through a shared language, although imperfect, and a close cultural background. The majority of Armenians who survived the genocide left as well. Sumru wants to know why Antranik did not accompany his children to Europe, and learns that he is worried that nobody would ever care for the church and that their heritage would be lost. Sumru recognizes that the region has experienced far older and similar losses and suffering.

Sumru wonders if Antranik has old Armenian elegy recordings, and on another visit, Antranik plays one elegy for her from his mother. He explains that his mother sang this elegy following the death of his brother, who perished in the Armenian genocide before Antranik was born. The notion of postmemory can be explored when Antranik addresses the genocide and his family's past. Belonging to the Armenian postgeneration, Antranik wishes to pass on the familial and communal legacy of Diyarbakir, which was formerly a major Armenian metropolis, wherever possible. Antranik has the postmemory of the genocide that he did not personally experience but gained through communication. He saw the presence of flourishing cultural life in the past and was traumatized by witnessing its destruction.

With Antranik's storyline, Future Lasts Forever turns to older traumas. The film does not set Armenian and Kurdish memories of past losses against each other, as in the competitive memory process diagnosed by Rothberg. It links the narratives of the Kurdish families and Antranik to demonstrate how, despite historical and contemporary contrasts, grief and traumas of diverse people may be united via effective cinematography. Furthermore, since the film only shows this similarity from Sumru's perspective, the multidirectional memory model is incomplete. Is there a chance for solidarity? It is important to remember that Antranik is only portrayed in solitude within the church throughout the film. Antranik does not have a scene with Ahmet, although Ahmet can be seen inside the church and 
heard referring to Antranik as "Uncle Anto". The links between traumatic events and fiction, are used to seek similarity and multidirectional memory. They are left unfinished when the representatives of the two ethnicities cannot physically contact each other within the film frame.

In both the actual and metaphorical senses, Future Lasts Forever is a travelling memory-film. Sumru travels to Diyarbakır, a place she has never visited before, which is significantly different from her homeland of Hopa in the Black Sea and her current residence of Istanbul. Sumru wanders around the city and investigates its culture throughout the film. The most visible dimension of the travelling memory-film, "physical travel", lasts throughout the film. ${ }^{37}$ It opens with a train trip of a group of college students, including Sumru and Harun. Sumru receives a letter from Harun, which she is to read later. With camera movement inside the train, time shifts and now only Sumru is seen. Harun's letter is read aloud in his voice: he declares his intention to join the Kurdish guerrillas. Harun's travel remains unknown; he expresses his desire to meet Sumru again but acknowledges that this would most likely not be possible. Although Harun leaves Sumru and his past life for good, he talks about the future and chances, so he sees his journey not as depressing or gloomy but somewhat optimistic. He finishes his letter with the words, After all, isn't it too hard to live without hope? Let us now make a promise and have faith to see sunny and beautiful days.

The film's abstract perception of travel may be interpreted as a journey from the darkness of war to a bright future, which is mentioned several times, particularly when referring to the ongoing peace process. Sumru and Ahmet discuss what will happen when the conflict is finished, and the Truth Commissions are established. They think that documents from the Memory Centre will undoubtedly serve as crucial evidence. They discuss the Truths Commissions, proposed by the parliament to be created between 2009 and 2011 to examine crimes in the Kurdish cities. While chatting about the future with Sumru on the night of their stay in Hakkari, Ahmet tells her that he imagined that institutes would be formed to investigate the country's forgotten languages and traditions, in keeping with the policies of the time. These moments demonstrate the film's link to the peace process, and despite its melancholy tone and emphasis on traumas, the film does depict a bright common destiny in the future.

The abstract notion of travel shows itself clearly with Sumru's transformation. Her position changes from a person who listens to others to a someone with a deeper story to tell. The scene when the narrative shift happens is when a wife of a forcibly disappeared person breaks one-sided communication and asks her: And who are you looking for?

Sumru, who has been a passive spectator, decides to embark on a trip to find Harun. Following this choice, the change in her position is also reflected visually. Sumru is seen in front of a wall with photographs of several historical events and personalities behind her. Sumru is thinking what to do with the various historical traumas that have been depicted. This moment is evocative of the scenes with families testifying. While they sat in front of photos of their relatives on the wall, Sumru has a long history of events behind her, none of which are necessarily related to her individual existence or family history: from the Prague Spring to the murder of Kurdish children, from RAF member Ulrike Meinhof to the murder of 
Turkish journalists and trade unionists. It can also be interpreted as an introduction to multidirectional memory dynamics. Even though Sumru deals with her personal trip and suffering, the film shows how memories and pain are linked.

\section{Intertextuality and anti-colonialism}

Intertextual references play an important role in Future Lasts Forever. The title of the film echoes the title of Louis Althusser's memoir. ${ }^{38}$ Alper himself stated that Althusser both personally reckons with his memory and deals with the issue of social confrontation and keeping the memory alive. Here I also have my optimism or an effort to breathe in that darkness. ${ }^{39}$ The film starts with a quote from Cesare Pavese's novel The House on the Hill: If one day the war ends, then well have to ask ourselves, what will we do with the dead, what did they die for? Pavese was an Italian antifascist, and his novel was published shortly after World War II; it tells the story of a teacher who flees the war and sees the horrors of war in his homeland. ${ }^{40}$

Even though the Armenian genocide and Kurdish conflict took place in the very same land, so the multidirectional relation is easier to see, the film also relates the Kurds' national struggle to other anti-colonialist movements. On the streets and even inside institutional buildings, numerous murals and posters convey additional meanings and generate intertextual readings. Hope is more precious than victory. The wretched of the earth, one of the graffiti declares. It alludes to the film's search for optimism and the book The Wretched of the Earth by Frantz Fanon. This reference to one of the best known and influential works on the anti-colonial movement would imply that the Kurdish struggle is inextricably linked to other anti-colonial conflicts worldwide. ${ }^{41}$ The graffiti can be seen as supporting material for Astrid Erll's opinion, so that the film can be interpreted as a practice of transcultural memory. ${ }^{42}$ Alper constantly narrates his story using the transcultural memory paradigm, which includes various references and memories, rather than just one cultural trauma.

\section{Conclusion}

After 2000, independent filmmaking took the chance to produce narratives based on identity rather than Turkey's mainstream history and memory themes. This movement seems to be significantly linked to the country's recent tragic experiences. Many memory-related debates have erupted as a result of cinematic representations of minorities and marginalized groups. Turkey's vast geography and the opportunities to live in a variety of cultures and identities make it a unique country. On the other hand, the unitarist regime wishes to acknowledge only the Turks' presence in official history. This is counterbalanced by the contribution of artistic works in which many traumas of various identities are exposed to debate.

Future Lasts Forever was a production made with international funding, independently from big production companies and capital owners, and adhering to realistic cinema aesthetics. Another sign of independence can be seen in the film's limited appeal to the target audience and its frequent appearances at film festivals and events. The film itself declares that it is a part of the New Cinema Movement, closing with the movement's emblem. 
Future Lasts Forever brings together Kurdish and Armenian tragedies from the past that have never been acknowledged in the country. The film tries to evoke in the viewer empathy for Kurds whose relatives were forcefully disappeared and Armenians who were forced to flee their country and abandoned to obscurity. In this regard, the film, which features the notion of multidirectional memory, also explores other memory topics. Future Lasts Forever is also a travelling memory-film that portrays the Armenian genocide in a post-memory setting. Alper's film is a realistic story that follows in the footsteps of Turkey's political and independent film pioneers.

${ }^{1}$ Since Turkey is not an ethnically homogeneous country, the author deliberately avoids referring to its people or cinema as "Turkish". Instead, descriptive paraphrases such as "people of Turkey" and "cinema of Turkey" will be used throughout the article.

${ }^{2} \mathrm{M}$. Rothberg, Multidirectional Memory: Remembering the Holocaust in the Age of Decolonization, Stanford University Press, Stanford 2009.

${ }^{3}$ A. Erll, "Travelling Memory in European Film: Towards a Morphology of Mnemonic Relationality", Image and Narrative 2017, vol. 18, no. 1.

4 M. Hirsch, The Generation of Postmemory, Columbia University Press, New York 2012.

${ }^{5}$ Yeşilçam (Tr. Green Pine) used as a metonym for the mainstream Turkish film industry. The name Yeşilçam comes from the Yeşilçam Street in Beyoğlu district of İstanbul, similarly to Hollywood in the US.

${ }^{6}$ M. Akser, "Locating Turkish Cinema Between Populist Tendencies and Art Cinema", in: The Palgrave Handbook of Asian Cinema, eds. A. H. J. Magnan-Park, G. Marchetti, S. K. Tan, Palgrave McMillan, London 2018, p. 153.

${ }^{7}$ Idem, "Türkiye'de Bağımsız Sinema Akımları Her Daim Bağımlı", Panorama Khas, http://panorama.khas.edu.tr/turkiyede-bagimsiz-sinema-akimlari-her-daim-bagimli-384 (accessed: 10.07.2020).

${ }^{8}$ Idem, "Turkish Independent Cinema: Between Bourgeois Auteurism and Political Radicalism", in: Independent Filmmaking Around the Globe, eds. D. Baltruschat, M. P. Erickson, University of Toronto Press, Toronto 2015, p. 136.

${ }^{9}$ E. Y1ld1z, "Lost Images, Silenced Past: Rethinking the Film Practices of Genç Sinema (Young Cinema) from 1968 to 1971", in: The Politics of Culture in Turkey, Greece and Cyprus: Performing the Left Since the Sixties, eds. L. Karakatsanis, N. Papadogiannis, Routledge, Abingdon 2017, p. 143.

${ }^{10}$ Güney shared the prize with another exiled director from his neighbouring country, Greece:
Costa Gavras, who received the award for the film Missing (1982)

${ }^{11}$ E. J. Zürcher, Turkey: A Modern History, I. B. Tauris, London 1993, p. 268-281.

${ }^{12}$ A. Bora, A. Günal, 90'larda Türkiye'de Feminizm, İletişim Yayınları, İstanbul 2016.

${ }^{13}$ Eşkıya Box Office Numbers, Box Office Türkiye, https://boxofficeturkiye.com/film/eskiya2012096 (accessed: 1.07.2020).

${ }^{14}$ A. Suner. Hayalet Ev: Yeni Türk Sinemasinda Aidiyet, Kimlik ve Bellek, Metis, İstanbul 2015.

${ }^{15}$ Turkey, Eurimages, https://www.coe.int/en/web/eurimages/turkey (accessed: 17.11.2021).

${ }^{16}$ M. Akser, op. cit., p. 142.

${ }^{17}$ A. Savran, "The Peace Process between Turkey and the Kurdistan Workers' Party, 2009-2015", Journal of Balkan and Near Eastern Studies 2020, vol. 22, no 6, p. 778 .

${ }^{18}$ Academics for Peace, "We Will Not Be a Party to This Crime", Barış Iç̧in Akademisyenler, https://barisicinakademisyenler.net/node/63 (accessed: 10.07.2020).

${ }^{19}$ Bia News Desk, "Probe Into Film Workers Supporting Peace Academics", bianet, http://bianet.org/english/human-rights/182058probe-into-film-workers-supporting-peaceacademics_(accessed: 10.07.2020).

${ }^{20}$ Ibidem.

${ }^{21}$ S. Girit, "Başrolde Aram değil Ali olsaydi filmim desteklenecekti", BBC Türkçe, https://www.bbc.com/turkce/haberler/2013/05/ 130523_cannes_ozcan_alper_ (accessed: 12.08.2021).

${ }^{22}$ Muslim people of Armenian origin living in the Black Sea Region of Turkey.

${ }^{23}$ Ö. Alper, "MKM: Kendi Dilinde Üretme İradesi", Altyazı Fasikül https://fasikul.altyazi.net/yazi/serbestkursu/mkm-kendi-dilinde-uretmeiradesi/ (accessed: 12.08.2021).

${ }^{24}$ Nar Film, https://www.narfilm.com/about (accessed: 21.11.2021).

${ }^{25}$ M. Rothberg, op. cit., p. 3.

${ }^{26}$ Ibidem, p. 2. 
${ }^{27}$ Ibidem, p. 9.

${ }^{28}$ Ibidem, p. 5

${ }^{29}$ Ibidem, p. 3

${ }^{30}$ Ibidem, p. 6-7.

31 A. Çelik, "Hatırlama fragmanlarından karşıhafıza peyzajının inşasına 1915 - IX", Yeni Yaşam Gazetesi, http://yeniyasamgazetesi1.com/hatirlama-fragmanlarindan-karsi-hafiza-peyzajinin-insasina-1915-ix-adnan-celik/ (accessed: 6.08.2020).

${ }^{32}$ A. Çelik, "The Armenian Genocide in Kurdish Collective Memory", Middle East Research and Information Project, https://merip.org/2020/08/the-armenian-genocide-in-kurdish-collective-memory/ (accessed: 6.08.2020).

${ }^{33}$ A. Erll, op. cit., p. 6.

${ }^{34}$ Ibidem, p. 6.
${ }^{35}$ Ibidem, p. 8-9.

${ }^{36}$ M. Hirsch, op. cit., p. 5.

${ }^{37}$ A. Erll, op. cit., p. 8-9.

${ }^{38}$ L. Althusser, The Future Lasts Forever: A Memoir, trans. R. Veasey, The New Press, New York 1993.

${ }^{39}$ E. Köstepen, B. Göl, “Özcan Alper ile söyleşi: Şimdi Değilse Ne Zaman?", Altyazı, https://altyazi.net/gozecarpanlar/ozcan-alperile-soylesi-simdi-degilse-ne-zaman/ (accessed: 30.06.2020).

${ }^{40}$ C. Pavese, The House on the Hill, trans. W. J. Strachan, Peter Owen Publishers, London 1987.

${ }^{41}$ F. Fanon, The Wretched of the Earth, trans. C. Farrington, Grove Weidenfeld, New York 1963.

${ }^{42}$ A. Erll, op. cit., p. 6.

Fatma Edemen

\section{Bibliography}

Akser, M. (2012). Türkiye’de Bağımsı Sinema Akımları Her Daim Bağımlı. Panorama Khas. https://panorama.khas.edu.tr/turkiyede-bagimsiz-sinema-akimlari-her-daim-bagimli-384

Çelik, A. (2020, April 8). The Armenian Genocide in Kurdish Collective Memory. Middle East Research and Information Project. https:/merip.org/2020/08/the-armenian-genocidein-kurdish-collective-memory/

Erll, A. (2017). Travelling Memory in European Film: Towards a Morphology of Mnemonic Relationality. Image and Narrative, 18 (1), pp. 5-19.

Hirsch, M. (2012). The Generation of Postmemory. New York: Columbia University Press.

Rothberg, M. (2009). Multidirectional Memory: Remembering the Holocaust in the Age of Decolonization. Stanford: Stanford University Press.

Suner, A. (2015). Hayalet Ev: Yeni Türk Sinemasinda Aidiyet, Kimlik ve Bellek. İstanbul: Metis. 
Slowa kluczowe:

film niezależny; studia nad pamięcią; pamięć wielokierunkowa; pamięć wędrująca; postpamięć
Abstrakt

Fatma Edemen

Film niezależny na rzecz solidarności traum w kinie Turcji

Pojęcie pamięci wielokierunkowej zostało wprowadzone przez Michaela Rothberga w 2009 r. w pracy Pamięć wielokierunkowa. Pamiętanie Zagłady w epoce dekolonizacji. Później zaś wielu innych badaczy wykorzystywało tę koncepcję do analizy dzieł sztuki, w tym także filmów. Choć dotyczy ona przede wszystkim kwestii możliwości ustanowienia solidarności między pamięcią czy traumą wspólnot odległych od siebie geograficznie i kulturowo, w tekście autorka zaznacza, jak kluczową rolę odgrywa to pojęcie w przypadku społeczności wielokulturowych oraz dotkniętych różnorodnymi traumami. Kategoria pamięci wielokulturowej, a w ślad za nią także koncepcja pamięci wędrującej czy postpamięci, są analizowane w kontekście niezależnego tureckiego filmu Future Lasts Forever (Gelecek Uzun Sürer, 2011) w reżyserii Özcana Alpera. Krytyczna refleksja na temat filmu pozwala ukazać wielokierunkową pamięć traumatycznej przeszłości Turcji jako szansę na rzeczywiste budowanie solidarności.

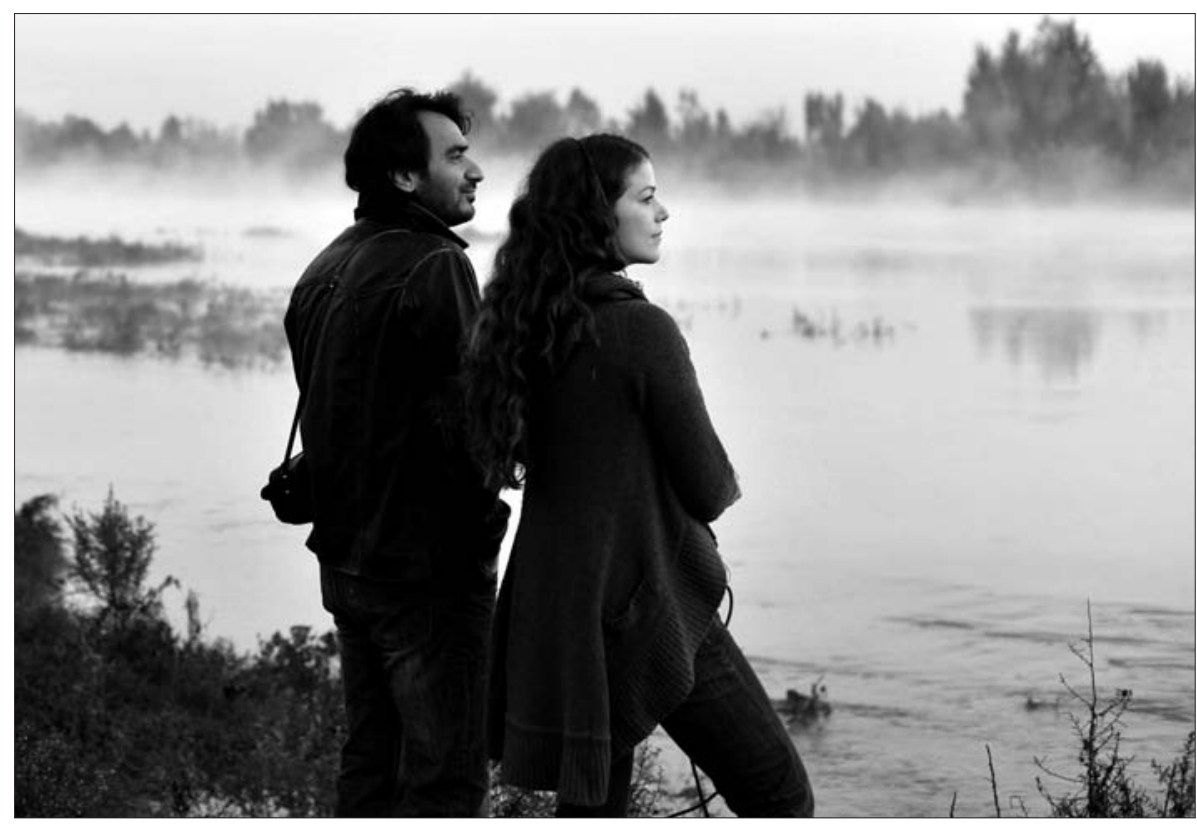

